\title{
Direct Seeded Rice and its Prospects in Nepal: A Review
}

\author{
Amrit Sharma ${ }^{1, a, *}$, Shaurav Sharma ${ }^{1, b}$, Pankaj Kumar Yadav ${ }^{1, c}$, Bibek Sodari $^{1, d}$ \\ ${ }^{1}$ Faculty of Agriculture, Agriculture and Forestry University, Rampur, Chitwan, Nepal \\ *Corresponding author
}

A R T I C L E I N F O A B S T R A C T

Review Article

Direct Seeded Rice (DSR) is an alternative cultivation technique to the conventional Transplanted Rice (TPR). In this method, seeds are directly sown to the field without the necessity of nursery raising and transplanting. DSR can generally be divided into dry-DSR (sowing dry seeds in dry soil), wet-DSR (sowing pre-germinated seeds in moist soil) and water-seeding (sowing dry or pre-

Received : 18/04/2021 Accepted : 05/05/2021 germinated seeds in standing water). This helps in saving water alongside the labour and results in early harvest due to quick crop establishment. DSR is proved to be sustainable and eco-friendly since it emits less methane than in TPR. However, there are few constraints associated with DSR such as weed infestation, crop lodging and nutrient loss. If these major issues are fixed, DSR can result in greater economic returns as compared to TPR. In absence of puddling, the soil structure can be maintained which leads to greater yields of succeeding crops. This technique has been successfully practiced in many countries like Srilanka, Malaysia and USA. In developing nations

Keywords:

Advantages

Constraints

Direct Seeded Rice (DSR)

Nepal

Prospects like Nepal, irrigation and labour constraints can be tackled by adopting direct-seeding for rice cultivation.

\section{Introduction}

\section{Rice}

Rice belongs to the family Gramineae. Oryza sativa L. is the most widely cultivated species of rice among 20 genera of Oryza (Fageria, 2007). Being staple food for more than half of the world, it is important to maintain the stable production of rice to feed the constantly growing human population (Roychowdhury et al., 2012). The total production of rice in the world is $782,000,147$ metric tons (FAOSTAT, 2018). It provides $30-75 \%$ of the total calories to more than 3 billion Asians (Kumar and Ladha, 2011a). Rice is grown in at least 114 countries globally and more than 50 countries have an annual production of over 0.1 million tons (Mt) (Pathak et al., 2011).

\section{Cultivation Techniques}

The conventional rice production system involves the rising of nursery seedlings followed by transplanting in puddled flooded soil. This process requires a lot of water, energy and labour resources. So, farmers around the globe have shifted their interest towards alternate cultivation practices (Nawaz et al., 2019). In order to cope with increasing labour costs, two significant changes have been History made historically in crop establishment methods. In temperate Asian countries such as Japan, Korea, and Taiwan, farm labour shortages have led to a transition from manual to mechanical transplantation whereas in tropical countries such as Malaysia and Thailand the trend has shifted to direct seeding (Pandey and Velasco, 2002).

\section{Direct Seeded Rice (DSR)}

Direct seeding involves the establishment of rice crops from seeds sown in the field instead of transplanting seedlings from the nursery (Farooq et al., 2011). The fields at least need to have sufficient moisture in DSR for successful germination unlike being flooded in TPR (Cabangon et al., 2002). In general, three principal methods of DSR are in practice viz. dry seeding (sowing dry seeds into dry soil), wet seeding (sowing re-germinated seeds on wet puddled soils) and water seeding (seeds are sown into standing water) (Farooq et al., 2011). The role of DSR has been realized especially in the low-income Asian countries with high population growth rates where the rice demand is estimated to increase by $30-50 \%$ over the next 30 years (Mortimer et al., 2008). 
Rice cultivation began when the hunting, fishing and food-gathering inhabitants near the rivers and along the foothills, dropped seeds into low-lying fields. Modern rice evolved as a result of persistent human and artificial selection (Chang, 1976). The domesticated species Oryza sativa i.e. Asian rice evolved 9,000 years ago and spread subsequently from its centre of origin (India and China) to the rest of the world (Purugganan, 2010). Despite several types of research and studies, the beginning of rice domestication still remains unclear (Z. Zhao, 2010). Oryza sativa, the most important commercial species of rice, is differentiated into three subspecies- indica, japonica and javanica based on their commercial production zones (Gadal et al., 2019). Compared to its culture in Asia, rice in southern Europe, the United States, and Australia have a relatively short history. Rice was introduced into Italy during the fourteenth and fifteenth centuries. In the United States, rice was first produced commercially in the middle of the eighteenth century and in Australia, rice was first produced in the twentieth century (Hill et al., 1991).

Historical accounts of rice cultivation in Asia indicate that, during its early period of domestication, the rice used to be dry sown in a mixture with other crops that were established under the shifting cultivation system (Pandey and Velasco, 2002). In the early twentieth century, Mekong Delta (Vietnam) farmers used direct seeding for their floating rice (Can and Xuan, 2002). By the 1950s, transplanting had become the dominant method of crop establishment in most of Asia. Dry seeding was practiced only in those areas where low population density or severe climatic/hydrological constraints prevented intensification of rice systems (Pandey and Velasco, 2002). Since the early 1980s, direct seeding of rice has quickly replaced transplanting because of increased cropping intensification, higher costs for transplanting, lack of farm labour, and the availability of short-duration rice varieties (Can and Xuan, 2002). Malaysia, Thailand, Vietnam, China adopted DSR in the second half of the twentieth century (Kumar and Ladha, 2011a)

\section{Types of DSR}

There are two methods of direct seeding rice, dry and wet seeding, based on the physical condition of the seed and seed environment. Wet seeding is further divided into aerobic wet seeding, anaerobic wet seeding, and water seeding, based on the oxygen level in the vicinity of germinating seeds. Rice seeds are broadcasted or drilled in rows on dry, moist, or puddled soil, whereas only aerial or mechanical broadcasting is done for water seeding (Balasubramanian and Hill, 2002). The presence of longitudinal aerenchyma channels facilitates oxygen diffusion from the shoots to the root tips, allowing rice plants to grow well in flooded paddy fields (Yamauchi et al., 2013).

Table 1. Classification of Direct-seeded Rice systems

\begin{tabular}{|c|c|c|c|c|c|c|}
\hline $\begin{array}{l}\text { Direct } \\
\text { seeding } \\
\text { method }\end{array}$ & $\begin{array}{l}\text { Seed bed } \\
\text { condition }\end{array}$ & Seed type & $\begin{array}{c}\text { Land } \\
\text { preparation } \\
\text { Procedure }\end{array}$ & Seeding Pattern & $\begin{array}{c}\text { Water regime }(0- \\
14 \text { days after } \\
\text { sowing })\end{array}$ & $\begin{array}{c}\text { Suitable area } \\
\text { for practice }\end{array}$ \\
\hline $\begin{array}{l}\text { Dry- } \\
\text { seeded } \\
\text { rice }\end{array}$ & $\begin{array}{l}\text { Dry soil } \\
\text { (unsaturated } \\
\text { or moist), } \\
\text { aerobic }\end{array}$ & Dry seed & $\begin{array}{l}\text { Dry, reduced or } \\
\text { zero tillage; } \\
\text { Ploughing and } \\
\text { harrowing with } \\
\text { sufficient } \\
\text { moisture }\end{array}$ & $\begin{array}{l}\text { Broadcasting, } \\
\text { Drilling } \\
\text { (mechanized seed } \\
\text { drill) or Sowing in } \\
\text { rows (mechanical } \\
\text { or manual) }\end{array}$ & $\begin{array}{l}\text { No standing water } \\
\text { until rice has } \\
\text { reached 3-leafed } \\
\text { stage) }\end{array}$ & $\begin{array}{l}\text { Rainfed } \\
\text { highland } \\
\text { (Bari) or dry } \\
\text { land with } \\
\text { precise } \\
\text { water } \\
\text { control }\end{array}$ \\
\hline $\begin{array}{l}\text { Wet- } \\
\text { seeded } \\
\text { rice }\end{array}$ & $\begin{array}{l}\text { Puddled } \\
\text { soil, } \\
\text { aerobic/ } \\
\text { anaerobic }\end{array}$ & $\begin{array}{l}\text { Pre- } \\
\text { germinated } \\
\text { seed }\end{array}$ & $\begin{array}{l}\text { Dry or wet } \\
\text { tillage; } \\
\text { ploughed, } \\
\text { flooded, } \\
\text { puddled and } \\
\text { levelled }\end{array}$ & $\begin{array}{l}\text { Broadcasting (by } \\
\text { hand or } \\
\text { mechanized } \\
\text { blower), Row } \\
\text { seeding (drum } \\
\text { seeder) }\end{array}$ & $\begin{array}{l}\text { Saturated soil } \\
\text { initially }(0-0.3 \mathrm{~cm} \\
\text { surface water })\end{array}$ & $\begin{array}{l}\text { Rainfed } \\
\text { lowland and } \\
\text { irrigated } \\
\text { areas with } \\
\text { good } \\
\text { drainage } \\
\text { facilities }\end{array}$ \\
\hline $\begin{array}{l}\text { Water- } \\
\text { seeded } \\
\text { rice }\end{array}$ & $\begin{array}{l}\text { Puddled or } \\
\text { unpuddled } \\
\text { soil, } \\
\text { Standing } \\
\text { water (3-5 } \\
\text { cm), mostly } \\
\text { anaerobic }\end{array}$ & $\begin{array}{l}\text { Dry or pre- } \\
\text { germinated }\end{array}$ & $\begin{array}{l}\text { Dry or wet } \\
\text { tillage; } \\
\text { ploughed, } \\
\text { flooded, } \\
\text { (puddled) and } \\
\text { levelled }\end{array}$ & $\begin{array}{l}\text { Broadcasting } \\
\text { (manual or } \\
\text { motorized blower) }\end{array}$ & $\begin{array}{l}\text { Standing water } \\
(5-10 \mathrm{~cm})\end{array}$ & $\begin{array}{l}\text { Irrigated } \\
\text { lowland with } \\
\text { proper land } \\
\text { levelling and } \\
\text { in areas with } \\
\text { red / weedy } \\
\text { rice problem }\end{array}$ \\
\hline
\end{tabular}

Modified from: (Balasubramanian and Hill, 2002; Joshi et al., 2013; Rao et al., 2007)

\section{Varieties of DSR}

DSR requires specially bred cultivars with the effective root system (Pantuwan et al., 2002), good mechanical strength in the coleoptiles, early seedling vigour for weed competitiveness and efficient root system (D. L. Zhao et al., 2006). Greater carbohydrate reserves in larger seeds support the adequate seedling growth (Namuco et al.,
2009). African rice is cultivated less intensively outside Africa. However, global interest has arisen lately because of its tolerance to abiotic stresses (Meyer et al., 2016). Genetic parameters for DSR varieties include grain yield per hill, spikelets per panicle, plant height, flag leaf width, flag leaf length, spikelets and no. of tillers per hill 
(Ragvendra et al., 2011). Tyagi and Chander (2020) have reported timely sowing of succeeding crops by 7-10 days using early maturing varieties(Tyagi and Chander, 2020). According to Dawadi and Chaudhary (2013), Hardinath-1 varieties produced significantly higher grain yield, net return and higher B: C ratio in DSR. In addition to these, greater grain and straw yields were observed in the crop shown on June 13 (Dawadi and Chaudhary, 2013a).

Table 2. Varietal response to DSR and TPR

\begin{tabular}{c|llccc}
\hline S.N & \multicolumn{1}{|c}{ Countries } & \multicolumn{1}{c}{ Varieties for DSR } & $\begin{array}{c}\text { Yield (tons/ } \\
\text { ha)TPR }\end{array}$ & $\begin{array}{c}\text { Yield (tons/ } \\
\text { ha) DSR }\end{array}$ \\
\hline 1 & Nepal & Sonamansuli, Hardinath-1, Sukhaa, Chaite, Radha-1, & 3.71 & 3.6 \\
2 & India & $\begin{array}{l}\text { Ram-dhan, Sabitri, Lokhnath-505 } \\
\text { Mahsuri-1, KrantiPusa-2511, Pusabasmati, Pant-dhan }\end{array}$ & 6.8 & 6.6 \\
3 & China & Lvhan-1, Huanghuazhan, Yangliang, Jiangsu & 8.1 & 10.4 \\
4 & Bangladesh & BRRI Dhan-39, BRRI Dhan-44, Zata & NA* & NA* \\
5 & Pakistan & KS-282 & 3.42 & 3.6 \\
6 & Philippines & IR64, IR10, IR42, C2, C4, UPL, RI-7 & 5.94 & 6.07 \\
\hline
\end{tabular}

Modified from: (Farooq et al., 2011), *NA: Not Available, Inbreds (Hardinath-1, Tarahara-1, Radha-4, Sukha-1, Sukha-2, Sukha-3, Ramdhan, Sabitri), Hybrids (Gorakhnath, Arize 6444, Bioseed 786, RH 245, Loknath-505, Raja) are recommended DSR varieties for terai and inner-terai of Nepal. Similarly, Khumal-4, Khumal-8, Khumal-10 are recommended for mid-hills whereas Chhomorong is recommended for the high hills of Nepal. (Devkota et al., 1999; M. L. Shah \& Bhurer, 2005)

\section{Present Status of DSR}

The largest producer of rice in the world is China followed by India, Indonesia, Bangladesh and Vietnam. The production share of Asia is the largest i.e. 90.2\%, followed by the America (5\%) and Africa (4.2\%) (FAOSTAT, 2018). The annual rice production of Nepal is $5,151,925$ tons, whereas that of China is $214,078,796$ tons and that of India is 172,580,000 tons. (FAOSTAT, 2018).

Direct seeded rice (wet and direct seeding) is about 95\% of the total rice grown in Sri Lanka (Weerakoon et al., 2011a). In Malaysia, DSR accounted for more than $90 \%$ of the total rice area planted by 2000 (Azmi et al., 2005). Rice is irrigated and mainly directly seeded in the Mekong River Delta of Vietnam. Wet seeding is more common however dry seeding, water seeding; zero tillage is also in practice (Azmi et al., 2005). Introduction of new herbicides, shortduration varieties (95 - 105 days), early establishment as well as harvesting of dry- DSR in August led to the cultivation of another rainfed rice and even the third crop during December to February in the Mekong River Delta region of Vietnam (Mortimer et al., 2008; My, 1995; Pandey and Velasco, 2002).

Farmers in the developed parts like the US, Europe and Australia practice direct seeding of rice with high mechanization, development of short duration, early maturing cultivars and proper nutrient management techniques including integrated weed management (Azmi et al., 2005). Rice cultivation in the US can be classified into water seeding (33\%) and dry DSR (67\%). It is mostly mechanized with the precise use of laser technology for proper land levelling, aircraft for seeding and pest control along with self-propelled combines for harvesting (Gathala, 2013).

DSR is likely to expand in Southeast Asia having low population density, higher wage rate and mechanization except in traditionally transplanted areas (Pandey and Velasco, 2002; S. P. Singh et al., 2008). DSR is being popular in Taihu Lake Basin (TLB) of China with more than $50 \%$ of the farmland under rice cultivation (Gao et al., 2006). The direct-seeded rice was found as a better alternative to TPR in Central China due to its less demand of labour, higher output to input ratio, higher NUE, improved uptake of nitrogen and identical grain yield (Liu et al., 2014).

In the northwestern Indo-Gangetic plains where ricewheat cultivation is dominant, zero tillage DSR provided higher yield, less irrigation water, increased net economic returns and reduction in the production cost in comparison to puddled transplanted rice. Further, double zero tillage can be an effective method of field preparation in ricewheat-growing regions (Gathala, 2013). DSR (wet and direct seeding) is about $95 \%$ of the total rice grown in Sri Lanka. The average yield of DSR in dry and wet zones is 5 tons per hectare and 3.3 tons per hectare respectively (Weerakoon et al., 2011b). In Bangladesh, DSR is mainly practised during pre-monsoon in the rainfed upland and also during monsoon in rainfed rice (Shelley et al., 2016). According to a study conducted in the Philippines, DSR was generally adopted in small, medium-sized farms rather than big farms due to economic incentives. DSR was mainly practised in the high elevated areas with water shortages alongside the areas with adequate irrigation systems (Satter and Bhuiyan, 1993).

M. Devkota et al. (2019) reported comparable yields and lower production cost (by $\$ 160 \mathrm{ha}^{-1}$ in DSR as compared to TPR) in western Terai of Nepal. In addition to this, water productivity was found to be greater by $4-18 \%$. This led to a net profit of \$ $122-232 \mathrm{ha}^{-1}$.

\section{Advantages of DSR}

The advantages of DSR over TPR include low water requirement during land preparation, early crop establishment and efficient use of early-season rainfall (Cabangon et al., 2002; My, 1995). Adoption of DSR resulted in less labour use, reduced variable and total cost per cultivated area which led to greater net returns (Isvilanonda, 2002). Transplanting is done mostly by the hired labour whereas the activities of DSR (soaking, transporting, broadcasting of seeds and replacing of seedlings) are done mostly by family labour (Ho and Romli, 2002). Dry seeding has several advantages over wet seedings, such as good seedling stand, lodging resistance, and less incidence of bird and fungi damage (Lee et al., 
2002a). As Direct seeding needs less tillage and no puddling, soil structure is maintained and makes soil aerobic. The absence of transplanting shock in DSR results in early maturity (7-10 days) which facilitates timely harvest and sowing of subsequent crops (Parthasarathi et al., 2012). Tripathi and his colleagues reported 13\%, 41\%, and $12 \%$ less usage of human labour, machine labour, and irrigation water respectively for DSR as compared to TPR (Tripathi et al., 2014). Shorter land preparation periods for wet seeded rice resulted in $19 \%$ less water consumption and 3-17\% higher yield (Tabbal et al., 2002).

Adoption of DSR saves about $40 \%$ of the labour required for nursery raising, uprooting and transplanting of seedlings (Pandey and Velasco, 2002) and 60\% of diesel energy associated with field preparation and irrigation (Pathak et al., 2011). In north-west India, seepage and percolation loss amounted to $43 \%$ and $56 \%$ of total water input for Dry DSR and traditional rice cultivation respectively. Around 35-40\% of water-saving was observed for dry DSR (Bhushan et al., 2007). Lee et al. (2002) reported a 30\% lower labour requirement and 20\% lower production cost in case of dry seeding than that for machine transplanted rice(Lee et al., 2002a). Singh et al. (2008) reported a profit of Rs 13,350 per ha for dry-seeded rice and Rs 11,592 per ha for wet-seeded rice as compared to Rs 10,343 per ha for transplanted rice(S. P. Singh et al., 2008). A national survey in China showed that on average farmers received $\$ 103$ per ha more with seedling broadcasting than with transplanting (Sheng-xiang, 2002).

\section{Constraints and their management in DSR}

The major constraints for DSR in the South Asian region include rainfed culture, poor drainage and slow economic growth (Pandey, 2002). Likewise, in China, poor crop establishment, weed infestation, lodging susceptibility and nitrous oxide gas emission have posed serious trouble. Continuous cropping and lack of variety development have led to yield decline in DSR. (Liu et al., 2014). DSR reduces the emission of $\mathrm{CH} 4$ however increases the emission of $\mathrm{N} 2 \mathrm{O}$ (especially under dry-DSR) (Qureshi et al., 2004). Higher N2O emission under zero tillage dry-DSR results in greater nitrogen loss (Hou et al., 2000).

\section{Weed Management}

Weed is one of the major constraints for the proper adoption of DSR. The average yield of rice from direct seeding was $3.3 \mathrm{t} /$ ha whereas that from transplantation was $3.7 \mathrm{t} / \mathrm{ha}$. The reduction in average yield for DSR was $10 \%$ as compared to TPR due to weed infestation (Qureshi et al., 2004). Weedy rice is a great threat to dry DSR because of its higher $\mathrm{N}$ use efficiency for biomass production as compared to cultivated rice (Liu et al., 2014). About 1800 species of weeds are reported in rice worldwide of which 50 are prominent in DSR. The major weeds of Direct Seeded Rice are Echinochloa spp., Ischaemum rugosum, Cyperus difformis, and Fimbristylis miliacea (Rao et al., 2007).

Combined efforts are necessary for effective weed management. Preparation of improved seedbed and tillage, use of weed resistance varieties and quality seeds, proper sowing time and narrow row spacing check the growth. In addition, use of crop residues as mulch, maintenance of uniform plant population, water depth and timing produce better results in DSR. Manual/ mechanical weeding alongside herbicide combination and rotation are recommended for optimum yield (Chauhan, 2012).

Comparable yield to weed-free condition is obtained when weeding is done for the first 60-75 days only or after 15 days of sowing. When two weedings are available, the best yield is obtained when weeding is done at 15-30 DAS and 45-60 DAS (G. Singh and Singh, 2008).

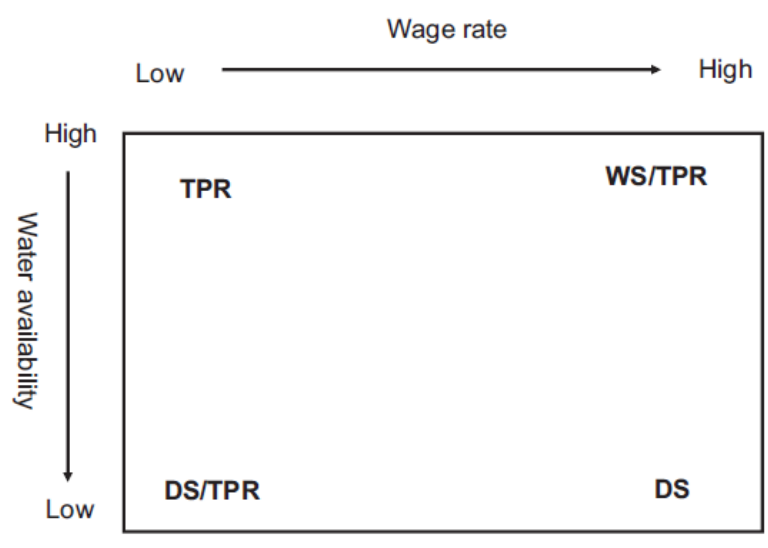

Figure 1. Factors affecting the choice of rice establishment methods.

Note: $\mathrm{TPR}=$ transplanting, $\mathrm{WS}=$ wet seeding, DS = dry seeding, Adapted from: (Farooq et al., 2011; Pandey and Velasco, 2002)

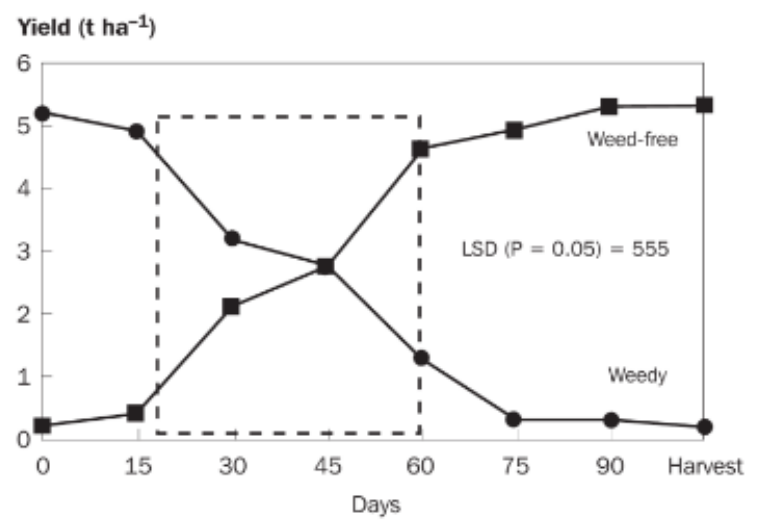

Figure 2. Critical duration of the weed-crop competition in dry-DSR

Adapted from: G. Singh and Singh (2008)

Stale seedbed preparation (7-10 days earlier) involves the stimulation of weed germination and emergence, facilitated by irrigated or rainwater. This is followed by their destruction using herbicides (paraquat or glyphosate) or shallow cultivation (G. Singh and Singh, 2008).

Mulching increases the net returns and B: C ratio in DSR as compared to non-mulch cultivation (G. S. Yadav et al., 2020). Gaire et al. (2013) reported increased productivity and reduced production cost with the use of Brown Manuring (Sesbania and Crotolaria) within 30 DAS in Chitwan and similar conditions. Eupatorium mulch one day after sowing showed promising results (3.5 t/ha) as compared to Sesamum Brown Manuring (2.97 t/ha), wheat straw mulch (2.83 t/ha) and controlled cultivation (1.77 t/ha). The B: C ratio of Eupatorium mulch for weed control was similar to herbicide application (2.4) (Gaire et al., 2013). 
Devsinghe et al. (2011) reported effective weed control using rice straw as mulch for Wet DSR but not in Dry-DSR (Devasinghe et al., 2011). In several countries of Asia, Africa and Latin America, hand weeding is practised partially or extensively (Rao et al., 2007). Conservational tillage which utilizes crop residue as mulch with improved crop and resource management practices enhanced the production and yield (Kumar et al., 2013).

The success of DSR cultivation can be attributed to the development and accessibility of modern herbicides. For dry- DSR, the best time for herbicide application is one just before the emergence and another within one week of permanent flooding (Kim et al., 1999).

Subbaiah (2008) suggested effective combinations of herbicides based on the research for weed control. In general, Butachlor and Safener were effective against grassy weeds whereas Pretilachlor and Safener were effective against grasses and sedges. Pyrazosulfuron-ethyl at low doses was effective against sedges and broadleaf weeds whereas Almix with surfactant was effective against broadleaf weeds.

Herbicide resistance is a great challenge associated with the repeated application of certain chemicals due to evolutionary responses (G. Singh and Singh, 2008). An integrated weed management system would be an effective, economical and eco-friendly approach for controlling weed in rice. However, a detailed study on the biology and ecology of weeds is needed for devising successful weed control measures (Yaduraju and Mishra, 2008).

Table 3. Herbicides and their application time and process

\begin{tabular}{|c|c|c|c|c|c|c|}
\hline Herbicide & $\begin{array}{l}\text { Active } \\
\text { component }\end{array}$ & $\begin{array}{l}\text { Time of } \\
\text { application }\end{array}$ & Target weeds & $\begin{array}{c}\text { Dose }(\mathrm{Kg} \\
\left.\text { a.i ha }{ }^{-1}\right)\end{array}$ & Mode of action & Type \\
\hline Paraquat & Paraquat & 1-2 DBS & $\begin{array}{l}\text { All types of } \\
\text { weeds }\end{array}$ & 0.5 & $\begin{array}{l}\text { Photosystem-I } \\
\text { electron divider }\end{array}$ & $\begin{array}{c}\text { Pre- } \\
\text { emergence }\end{array}$ \\
\hline Pendimethalin & $\begin{array}{l}\text { Pendimethalin } \\
(34 \% \mathrm{w} / \mathrm{w})\end{array}$ & 1-2 DAS & $\begin{array}{l}\text { Grasses broad } \\
\text { leaves }\end{array}$ & 1.0 & $\begin{array}{l}\text { Microtubule } \\
\text { assembly inhibitor }\end{array}$ & $\begin{array}{c}\text { Pre- } \\
\text { emergence }\end{array}$ \\
\hline Pretilachlor & $\begin{array}{l}\text { Pretilachlor } \\
(30 \% \mathrm{w} / \mathrm{v}) \mathrm{EC}\end{array}$ & 1-2 DAS & $\begin{array}{l}\text { All types of } \\
\text { weeds }\end{array}$ & 1.5 & $\begin{array}{l}\text { Inhibitor of long } \\
\text { chain fatty acid } \\
\text { synthesis }\end{array}$ & $\begin{array}{c}\text { Pre- } \\
\text { emergence }\end{array}$ \\
\hline Glyphosate & Glyphosate & 7-15DBS & $\begin{array}{l}\text { All types of } \\
\text { weeds }\end{array}$ & $1.2-1.6$ & $\begin{array}{l}\text { EPSP synthase } \\
\text { inhibitor }\end{array}$ & $\begin{array}{c}\text { Pre- } \\
\text { emergence }\end{array}$ \\
\hline Ethoxysulfuron & Ethoxysulfuron & 10-15 DAS & $\begin{array}{l}\text { Sedges, broad } \\
\text { leaves }\end{array}$ & 1.5 & ALS inhibitor & $\begin{array}{l}\text { Post- } \\
\text { emergence }\end{array}$ \\
\hline $2,4-\mathrm{D}$ & $2,4-\mathrm{D}$ & 20-25 DAS & $\begin{array}{l}\text { Sedges, broad } \\
\text { leaves }\end{array}$ & 0.5 & Synthetic auxin & $\begin{array}{l}\text { Post- } \\
\text { emergence }\end{array}$ \\
\hline
\end{tabular}

Note: DAS- Days after sowing, DBS- Days before sowing, a.i.- active ingredient, EPSP= 5-enolpyruvylshikimate-3-phosphate, ALS= Acetolactate Synthase, Modified from: Pathak et al. (2011); Kumar and Ladha (2011a)

\section{Lodging Management}

In wet and water seeding done at the surface level, the lodging problem is prominent at maturity. (Balasubramanian and Hill, 2002). The main lodginginducing factors in broadcasted rice are the shallow root distribution and shallow depth of buried culm base (Lee et al., 2002a). According to Lee et al (2002), high amounts of $\mathrm{N}$ application also increases field lodging (Lee et al., 2002 b). Lodging results in a sizable reduction in grain yield due to decreased photosynthesis by self-shading and hampers grain quality (Liu et al., 2014). It can reduce the yield of rice by $1 \mathrm{t} \mathrm{ha}^{-1}$ (Nawaz et al., 2019). Mechanical, as well as manual harvesting of a lodged crop, is extremely cumbersome (Liu et al., 2014).

Proper irrigation management reduces the incidence of lodging. Once the seedling stand is established, the rice crop needs to be irrigated at the third-leaf stage (25-30 DAS) requiring two or three drainages to increase lodging resistance (Lee et al., 2002b). High root lodging tolerant varieties were characterized by thicker root diameter (1mm), higher amount of root weight and vertical rooting distribution into the soil layer (Kim et al., 1993). Several types of research at the gene level have been conducted to develop the lodging resistance cultivars in rice. Yadav et al (2017) have mapped 12 QTLs (Quantitative Trait Loci) associated with lodging resistance traits viz. culm length, diameter and strength (S. Yadav et al., 2017). Hirano et al
(2014) identified 9 rice mutant lines possessing improved culm strength. These mutant lines might be useful in the development of lodging resistance variety for DSR (Hirano et al., 2014). Foliar application of growth retardants like Paclobutrazol (50 or $100 \mathrm{ppm}$ ) retards internode, culm length and increases the culm diameter. This results in greater bending resistance and maintains optimum yield (Rani Sinniah et al., 2012).

\section{Nutrient Management}

The recommended level of Nitrogen in dry-DSR is 150$180 \mathrm{Kg}$ per ha which is $40-70 \mathrm{Kg}$ higher than that for TPR and wet-DSR. Phosphate and potassium are applied at the same rate for TPR and Wet-DSR i.e. 70 and $80 \mathrm{Kg} \mathrm{ha}^{-1}$ respectively (Lee et al., 2002b). Split application of fertilizers enhances the efficiency and improves the germination percentage alongside the crop establishment. One-third of Nitrogen should be applied as basal dose followed by two equal splits at active tillering and panicle initiation (Kamboj et al., 2012). The use of rock phosphate is reported to be a cheaper source of Phosphorus for DSR especially when legume is included in the system (Bhattacharyya et al., 2002).

The yield of TPR was found to be lower than that of DSR without the application of Nitrogen. Manipulating the fertilizer management practices increases Nitrogen Use Efficiency (NUE) and grain yield in DSR. (Pandey, 2002). 
However, the NUE is less than $40 \%$ of applied $\mathrm{N}$ in flooded rice. (Craswell and De Datta, 1980). Denitrification, volatilization, and leaching losses are greater in dry-DSR than in TPR (Davidson, 1991). Leaf colour chart (LCC) can be used for Nitrogen management in which $\mathrm{N}$ is applied when the leaf colour falls below the critical limit (Kamboj et al., 2012).

The improper application of $\mathrm{N}$ fertilizer in DSR results in lower availability of Nitrogen, Phosphorus and micronutrients such as Zn, Fe, Mn and S (Gao et al., 2006; Ponnamperuma, 1972). The principal factors governing the nutrient dynamics in DSR are land preparation and water management. (Farooq et al., 2011). Fe availability in the soil increases slightly with the prolonged submerged condition. (Pandey, 2002). However, Fe deficiency is greater during early growth periods in DSR due to poor water management. It can be corrected with foliar application of FeSO4 (2-3\%). (Subbaiah, 2008). Excessive uptake of $\mathrm{Fe}^{2+}$ results in bronzing of rice leaves which leads to substantial yield loss (Becker and Asch, 2005). A greater concentration of $\mathrm{Fe}^{2+}$ and $\mathrm{Mn}^{2+}$ in soil solution has antagonistic effects on $\mathrm{Zn}$ absorption (Giordano et al., 1974).

Integrated Nutrient Management (INM) technique involving judicious application of NPK at 90:45:45 $\mathrm{kg} \mathrm{ha}^{-1}$ and FYM at $5 \mathrm{t} \mathrm{ha}^{-1}$ is reported to be efficient for DSR. (Dawadi and Chaudhary, 2013b).

\section{Disease and Pest Management}

The tendency of the outbreak of diseases and pests is more in Wet-DSR than in TPR (Pongprasert, 1995). According to Tomar (2002) in rainfed lowlands, higher temperature and humidity facilitates the buildup of pest populations. Balasubramanian and Hill (2002) reported higher pest and disease incidence in DSR due to dense canopy and less ventilation around plants (especially in broadcast-sown rice with a high seed rate.). The major insect pests in DSR are brown planthopper [Nilaparvata lugens], rice thrips [Stenchaetothrips biformis], green leafhopper [Nephotettix virescens], leaffolder [Cnaphalocrocis medinalis] and gall midge [Orseolia oryzae] (Pongprasert, 1995). Ants, yellow stem borer and hispa also cause significant damage in rice (Tomar, 2002). Other insect pests that attack emerging rice seedlings are the golden apple snail (Pomacea canaliculata) and rats. Protecting young seedlings against these pests is more difficult in W-DSR than in TPR (Balasubramanian and Hill, 2002). Root-knot nematodes have been observed when switching from flooded to water conservation rice production systems like dry DSR (Farooq et al., 2011).

High diseases susceptibility was observed when the rate of seedling exceeded 200 per sq $\mathrm{m}$. Similarly, a greater incidence of diseases was observed with a high amount of $\mathrm{N}$ application. ((Lee et al., 2002a). The major diseases in DSR are rice blast (Pyricularia grisea), sheath blight (Rhizoctonia solani), sheath rot (Sarocladium oryzae), and dirty panicle (Alternaria padwickii, Curvularia lunata, Fusarium moniliforme, Bipolaris oryzae)ragged stunt virus (Vector-Nilaparvata lugens), and yellow-orange leaf virus (Vector-Nephotettix virescens) (Pongprasert, 1995). The severity of rice blast increases under water limited conditions (Farooq et al., 2011). According to Wada (2002), high plant density resulting in high humidity in broadcast fields accelerates the occurrence of diseases such as rice sheath blight. In DSR, different species of Pseudomonas like $P$. fluorescens, $P$. aeruginosa and species of Bacillus like B. subtilis, B. pumilus are effective biocontrol agents against diseases like Rice blast, Brown spot, Bacterial blight and Sheath blight (Vasudevan et al., 2002).

Only selective insecticides (such as buprofezin for planthopper) should be used against specific insects. This helps to preserve the natural enemies of insects (Wada, 2002). Adoption of the IPM strategy by combining resistant varieties, predator management, cultural practices, and/or the judicious application of pesticides will help control most insects (Balasubramanian and Hill, 2002). Whereas, IDM (Integrated Disease Management) is a multidisciplinary approach that seems promising to manage diseases effectively by integration of cultural, physical, biological and chemical strategies (Kumar et al., 2013).

\section{Water Management in DSR}

Precise water management is very important in dry drilled seeded rice, especially during the crop emergence phase (Kumar and Ladha, 2011a). Uniform spread of water in dry-DSR reduces the problem of submergence as well as drainage (Lantican et al., 1999; Tuong et al., 1994). Precise land levelling saves up to $25 \%$ of irrigation water (Rickman, 2002). (Kumar and Ladha, 2011a) recommended sowing of plants 10-15 days before the onset of monsoon. The proper time of sowing enhances the water use efficiency by $40-50 \%$ and productivity by $30 \%$. Bund management maintains water depth and prevents water loss through seepage and leakage (Lantican et al., 1999; Tuong et al., 1994).

A flush of irrigation is necessary after sowing when there is no sign of rainfall. The field should be saturated with water at the three-leaf stage (Bouman, 2007). This helps in adequate germination, effective seedling establishment and plant growth (Kumar and Ladha, 2011b). In order to avoid water stress during flowering, the field needs to be flooded one week earlier (Bouman, 2007). The alternate wetting and drying (AWD) method of irrigation involves flooding the fields to the shallow depth of $5 \mathrm{~cm}$ and re-irrigating after the disappearance of water. The interval of AWD irrigation is more in Dry-DSR than in CT-TPR due to less cracking in the former. However, insufficient knowledge regarding the effect of AWD and poor irrigation facilities are the major constraints associated with the adoption of this method (Humphreys et al., 2010). Residue mulching is effective in dry-DSR, especially prior to monsoon when evapotranspiration loss is very high and plants are small (Jalota and Arora, 2002). The irrigation water requirement can be lowered by using short to medium duration cultivars that can sustain in limited water(Humphreys et al., 2010). Short episodes of drought during the flower exposure decreases panicle water potential and starch content required for pollen viability resulting in another dehiscence. This in turn produces large sterile panicles. Irrigation management during critical stages and foliar spray of Boron during flowering decreases the panicle sterility in DSR (Rehman et al., 2014). 


\section{Miscellaneous}

Priming seeds with water before direct seeding promotes uniform and vigorous germination and faster seed emergence (1-3 days) (Harris et al., 2002). Similarly, priming the seeds with $14 \% \mathrm{KCl}$ solution and saturated CaHPO4, increases established plant density, final tiller number and grain yield in very dry soil. However, under saturated soil conditions, seed priming with the same solution decreases the plant density and grain yield. Seed priming reduces the seeding rate in drought-prone areas(Du and Tuong, 2002).

\section{Prospects of DSR in Nepal}

Increased labour costs, scarcity of water and availability of herbicides have shifted the attention from TPR to DSR in recent years (Yaduraju and Mishra, 2008). Labour and water shortages during transplanting led to delay in cultivation and reduce rice yield in less mechanized countries. One of the main reasons for introducing DSR is to reduce the risk of establishment failure due to water shortage in the rice field at an appropriate transplanting time (Fukai, 2002). Out of 2.04 million ha cultivable land in Nepal, around 1.43 million ha land has surface and groundwater irrigation facilities. In rural areas, over $75 \%$ of irrigated land is occupied by groundwater. (T. Shah et al., 2006). Water conservation is essential to achieve yield stability and optimization in rice production (McDonald et al., 2006). Late arrival of monsoon rain in reduced tillage condition decreases the crop establishment and delays the maturity of transplanted seedlings (De Datta and Nantasomsaran, 1991). The shallow groundwater and surface flow elements associated with the monsoon rain creates the rice-growing conditions in Nepal. When rainfall is low, drought stress is the primary growth constraint for rice cultivation (Hobbs et al., 1996). DSR followed by Zero Tillage Wheat (ZTW) produced satisfactory yield, reduced cost of production and irrigation in western Terai of Nepal. In addition, it assisted in timely sowing and mitigating the risk of climate change (M. Devkota et al., 2019). Over 4 million labour approvals have been issued by the Department of Foreign Employment (Nepal) from 2008/09 to 2018/19 (Nepal Migration Profile, 2019). Migration changes the structure of labour markets which reduces the supply of agrarian labour (Sunamand McCarthy, 2016). It leads to deactivation (migrant households engage less in farming for their livelihood) and repeasantization (landless and poor non-migrant households have more access to the land left by migrants). This results in the availability of land among non-migrants, however, creates labour shortages for farming (Van der Ploeg, 2009; Vandergeest, 2012). In Nepal, around 20\% of the returnee migrant workers are employed in the Agriculture sector (Migration report, 2020). These figures reflect the prospect of alternative technique like DSR for rice cultivation in developing countries like Nepal.

Table 4. Description of Different Growth stages of rice

\begin{tabular}{|c|c|c|c|}
\hline Growth stage & DAS & Description & DSR management practice \\
\hline Germination & 5 & Coleoptile tip becomes visible & $\begin{array}{l}\text { Pre-emergence herbicide } \\
\text { application, Irrigation }\end{array}$ \\
\hline Tillering initiation & 19 & First tiller is visible from the main shoot & $\begin{array}{l}\text { Mechanical or chemical weed } \\
\text { management }\end{array}$ \\
\hline Active tillering & 45 & Maximum tillering per unit time occurs & Urea split-dose application \\
\hline $\begin{array}{l}\text { Panicle primordia } \\
\text { initiation }\end{array}$ & 61 & Panicle initiation starts & Irrigation \\
\hline Booting & 85 & $\begin{array}{l}\text { The panicle is within the uppermost leaf } \\
\text { sheath }\end{array}$ & - \\
\hline Flowering & 95 & Flowers become visible on the panicle & Irrigation \\
\hline Physiological maturity & 120 & Grains become ripened & Panicles become ready to harvest \\
\hline
\end{tabular}

Note: DAS- Days after sowing, Modified from: Fageria (2007)

\section{Conclusion}

Different types of DSR practices (dry-DSR, wet-DSR and water seeding) can be adopted in Nepal for rice cultivation. These techniques have advantages over TPR due to lower inputs with comparable yield as well as quick crop establishment (by reducing transplanting shock) leading to an early harvest. Irregular monsoon rain and lack of adequate irrigation facilities in Nepal can be managed with the adoption of DSR. Labour shortages due to foreign employment have created troubles for land preparation and cultivation. These challenges can also be fixed to some extent by DSR practice since it demands less manual labour. Dry-DSR is promising for the regions with greater water scarcity such as rainfed uplands. This practice can be successfully implemented in spring rice due to the reduction of weed infestation and efficient use of water. DSR has been reported to be eco-friendly and sustainable as it emits less methane which is a prominent greenhouse gas. At present, more detailed studies and specialized researches are required at the local level on diverse aspects of DSR such as variety selection, seeding rate, management of weed, water and nutrients alongside diseases and pests. Concerned authorities like International Rice Research Institute (IRRI), Nepal Agriculture Research Council (NARC) and National Rice Research Programme (NRRP) should facilitate the research and extension programmes. Development and dissemination of technology (improved seeds, herbicides, weeder, seeder, cultivator, harrows) should be prioritized. Government should provide subsidies and insurance to motivate farmers to adopt DSR which may uplift the living standards of marginalized farmers. 


\section{Acknowledgement}

We would like to thank our parents, teachers and colleagues whose support and encouragement helped us complete this review.

\section{References}

Azmi M, Chin DV, Vongsaroj P, Johnson DE. 2005. Emerging issues in weed management of direct-seeded rice in Malaysia, Vietnam, and Thailand. Rice Is Life: Scientific Perspectives for the 21st Century: 196-198.

Balasubramanian V, Hill JE. 2002. Direct seeding of rice in Asia: Emerging issues and strategic research needs for the $21 \mathrm{st}$ century. Direct Seeding: Research Strategies and Opportunities: 15-39.

Becker M, Asch F. 2005. Iron toxicity in rice Conditions and management concepts. Journal of Plant Nutrition and Soil Science, 168(4):558-573.

Bhattacharyya HC, Singh VP, Borkakati, K. 2002. Nutrient management of direct-seeded rice in different ecosystems of eastern India. FOREWORD Vii ACKNOWLEDGMENTS Viii, 315.

Bhushan L, Ladha JK, Gupta RK, Singh S, Tirol-Padre A, Saharawat YS, Gathala M, Pathak H. 2007. Saving of water and labor in a rice-wheat system with no tillage and direct seeding technologies. Agronomy Journal, 99(5), 1288-1296.

Bouman BAM. 2007. Water management in irrigated rice: Coping with water scarcity. Int. Rice Res. Inst.

Cabangon RJ, Tuong TP, Abdullah NB. 2002. Comparing water input and water productivity of transplanted and directseeded rice production systems. Agricultural Water Management, 57(1): 11-31.

Can ND, Xuan VT. 2002. Environmental conditions as determinants of direct seeding techniques in different ecosystems in the Mekong Delta of Vietnam. Proceedings of the International Workshop on Direct Seeding in Asian Rice ystems: Strategic Research Issues and Opportunities"(S. Pandey, M. Mortimer, L. Wade, TP Tuong, K. Lopez, and B. Hardy, Eds.): 75-86.

Chang T. 1976. The rice cultures. Philosophical Transactions of the Royal Society of London. B, Biological Sciences, 275(936):143-157.

Chauhan BS. 2012. Weed ecology and weed management strategies for dry-seeded rice in Asia. Weed Technology, 26(1): 1-13.

Craswell ET, De Datta SK. 1980. Recent developments in research on nitrogen fertilizers for rice.

Davidson EA. 1991. Fluxes of nitrous oxide and nitric oxide from terrestrial ecosystems. Microbial Production and Consumption of Greenhouse Gases: Methane, Nitrogen Oxides, and Halomethanes.:219-235.

Dawadi KP, Chaudhary NK. 2013. Effect of Sowing Dates and Varities on Yield and Yield Attributes of Direct Seeded Rice in Chitwan Condition. Journal of Agriculture and Environment, 14: 121-130.

De Datta SK, Nantasomsaran P. 1991. Status and prospects of direct seeded flooded rice in tropical Asia. Direct Seeded Flooded Rice in the Tropics: 1-16.

Devasinghe D, Premarathne KP, Sangakkara UR. 2011. Weed management by rice straw mulching in direct seeded lowland rice (Oryza sativa L.).

Devkota K, Ranjit JD, Sherchan DP, Regmi A, Akhtar T, Humphreys E, Chauhan BS. 1999. Guidelines for Dry Seeded Rice (DSR): In the Terai and Mid Hills of Nepal.

Devkota M, Devkota KP, Acharya S, McDonald AJ. 2019. Increasing profitability, yields and yield stability through sustainable crop establishment practices in the rice wheat systems of Nepal. Agricultural Systems, 173:414-423.
Du LV, Tuong TP. 2002. Enhancing the performance of dryseeded rice: Effects of seed priming, seedling rate, and time of seedling. Direct Seeding: Research Strategies and Opportunities, International Research Institute, Manila, Philippines:241-256.

Fageria NK. 2007. Yield physiology of rice. Journal of Plant Nutrition, 30(6): 843-879.

FAOSTAT, 2018. 2018. FAOSTAT. http://www.fao.org/ faostat/en/\#data/QC

Farooq M, Siddique KH, Rehman H, Aziz T, Lee D-J, Wahid A. 2011. Rice direct seeding: Experiences, challenges and opportunities. Soil and Tillage Research, 111(2):87-98.

Fukai S. 2002. Rice cultivar requirements for direct seeding in rainfed lowlands. International Workshop on Direct Seeding in Asian Rice Systems'.(Eds S Pandey, M Mortimer, L Wade, TP Tuong, K Lopez, B Hardy.) :257-270.

Gadal N, Shrestha J, Poudel MN, Pokharel B. 2019. A review on production status and growing environments of rice in Nepal and in the world. Archives of Agriculture and Environmental Science, 4(1):83-87.

Gaire R, Dahal KR, Amgain LP. 2013. Effect of different mulching materials on weed dynamics and yield of direct seeded rice in Chitwan, Nepal. Agronomy Journal of Nepal, $3: 73-81$.

Gao X, Zou C, Fan X, Zhang F, Hoffland E. 2006. From flooded to aerobic conditions in rice cultivation: Consequences for zinc uptake. Plant and Soil, 280(1):41-47.

Gathala MK. 2013. Saharawat YS, Jat HS, Singh M, Kumar A, Jat ML, Humphreys E, Sharma DK, Sharma S, Ladha JK. Optimizing intensive cereal-based cropping systems addressing current and future drivers of agricultural change in the northwestern Indo-Gangetic Plains of India. Agriculture, Ecosystems and Environment, 177: 85-97.

Giordano PM, Noggle JC, Mortvedt JJ. 1974. Zinc uptake by rice, as affected by metabolic inhibitors and competing cations. Plant and Soil, 41(3):637-646.

Harris D, Tripathi RS, Joshi A. 2002. On-farm seed priming to improve crop establishment and yield in dry directseeded rice. Direct Seeding: Research Strategies and Opportunities, International Research Institute, Manila, Philippines:231240.

Hill JE, Bayer DE, Bocchi S, Clampett WS. 1991. Direct seeded rice in the temperate climates of Australia, Italy, and the United States. Direct Seeded Flooded Rice in the Tropics: Selected Papers from the International Rice Research Conference, 27-31 August 1990, Seoul, Korea, 91.

Hirano K, Okuno A, Hobo T, Ordonio R, Shinozaki Y, Asano K., Kitano H, Matsuoka M. 2014. Utilization of Stiff Culm Trait of Rice smos1 Mutant for Increased Lodging Resistance. PLOS ONE, 9(7), e96009. https://doi.org/10.1371/ journal.pone.0096009

Ho N-K, Romli Z. 2002. Impact of direct seeding on rice cultivation: Lessons from the Muda area of Malaysia. Direct Seeding: Research Strategies and Opportunities, 398.

Hobbs PR, Harrington LW, Adhikary C, Giri GS, Upadhyay S. R, Adhikary B. 1996. Wheat and rice in the Nepal Tarai: Farm resources and production practices in Rupandehi District. CIMMYT.

Hou AX, Chen GX, Wang ZP, Van Cleemput O, Patrick Jr WH. 2000. Methane and nitrous oxide emissions from a rice field in relation to soil redox and microbiological processes. Soil Science Society of America Journal, 64(6):2180-2186.

Humphreys E, Kukal SS, Christen EW, Hira GS, Sharma RK. 2010. Halting the groundwater decline in north-west IndiaWhich crop technologies will be winners Advances in Agronomy, 109:155-217.

Isvilanonda S. 2002. Development trends and farmers' benefits in the adoption of wet-seeded rice in Thailand. In Direct Seeding: Research Strategies and Opportunities: 115-124. 
Jalota SK, Arora VK. 2002. Model-based assessment of water balance components under different cropping systems in north-west India. Agricultural Water Management, 57(1): 75-87.

Joshi E, Kumar D, Lal B, Nepalia V, Gautam P, Vyas AK. 2013. Management of direct seeded rice for enhanced resource-use efficiency. Plant Knowledge Journal, 2(3): 119.

Kamboj BR, Kumar A, Bishnoi DK, Singla K, Kumar V, Jat ML, Chaudhary N, Jat HS, Gosain DK, Khippal A. 2012. Direct seeded rice technology in western Indo-Gangetic Plains of India: CSISA experiences. CSISA.

Kim J-K, Lee M-H, Oh Y-J. 1993. Lodging pattern of rice plant in broadcast-seeded and hand-transplanted cultivation. Korean Journal of Crop Science, 38(3): 219-227.

Kim J-K, Peng S, Park S-T. 1999. Direct seeding technology for irrigated rice in Asia. The Journal of The Korean Society of International Agriculture.

Kumar V, Ladha JK. 2011. Direct seeding of rice: Recent developments and future research needs. Advances in Agronomy, 111: 297-413.

Kumar V, Singh S, Chhokar RS, Malik RK, Brainard DC, Ladha JK. 2013. Weed management strategies to reduce herbicide use in zero-till rice-wheat cropping systems of the IndoGangetic Plains. Weed Technology, 27(1): 241-254.

Lantican MA, Lampayan RM, Bhuiyan SI, Yadav MK. 1999. Determinants of improving productivity of dry seeded rice in rainfed lowlands. Experimental Agriculture, 35(2): 127-140.

Lee MH, Kim JK, Kim SS, Park ST. 2002. Status of dry-seeding technologies for rice in Korea. Direct Seeding: Research Strategies and Opportunities"(S. Pandey, M. Mortimer, L. Wade, TP Tuong, K. Lopez, and B. Hardy, Eds.): 161-176.

Liu H, Hussain S, Zheng M, Sun L, Fahad S, Huang J, Cui K, Nie L. 2014. Progress and constraints of dry direct-seeded rice in China. J. Food Agric. Environ, 12:465- 472.

McDonald AJ, Riha SJ, Duxbury JM, Steenhuis TS, Lauren JG. 2006. Water balance and rice growth responses to direct seeding, deep tillage, and landscape placement: Findings from a valley terrace in Nepal. Field Crops Research, 95(2):367-382. https://doi.org/10.1016/j.fcr.2005.04.006

Meyer RS, Choi JY, Sanches M, Plessis A, Flowers JM, Amas J., Dorph K, Barretto A, Gross B, Fuller DQ. 2016. Domestication history and geographical adaptation inferred from a SNP map of African rice. Nature Genetics, 48(9):1083-1088.

Nepal labour migration report 2020. Https://nepalindata.com/ resource/nepallabour-migration-report-2020/

Mortimer AM, Riches CR, Mazid M, Pandey S, Johnson DE. 2008. Issues related to direct seeding of rice in rainfed cropping systems in northwest Bangladesh. Direct Seeding of Rice and Weed Management in the Irrigated RiceWheat Cropping System of the Indo-Gangetic Plains, :272-278.

My TV. 1995. Dry seeding rice for increased cropping intensity in Long An Province, Vietnam. Vietnam and IRRI: A Partnership in Rice Research :111-122.

Namuco OS, Cairns JE, Johnson DE. 2009. Investigating early vigour in upland rice (Oryza sativa L.): Part I. Seedling growth and grain yield in competition with weeds. Field Crops Research, 113(3): 197-206.

Nawaz A, Awan MI, Ijaz M, Hussain M, Ahmad S, Farooq M. 2019. Direct Seeding in Rice: Problems and Prospects. In Agronomic Crops :199-222. Springer.

Nepal Migration Profile. 2019. Migration in Nepal: A COUNTRY PROFILE 2019-| IOM Online Bookstore. https://publications.iom.int/books/migration-nepalcountryprofile-2019

Pandey S, Velasco L. 2002. Economics of direct seeding in Asia: Patterns of adoption and research priorities. Direct Seeding: Research Strategies and Opportunities: 3-14.

Pandey S. 2002. Direct seeding: Research strategies and opportunities. Int. Rice Res. Inst.
Pantuwan G, Fukai S, Cooper M, Rajatasereekul S, O'Toole JC. 2002. Yield response of rice (Oryza sativa L.) genotypes to different types of drought under rainfed lowlands: Part 1. Grain yield and yield components. Field Crops Research, 73(2-3): 153-168.

Parthasarathi T, Vanitha K, Lakshamanakumar P, Kalaiyarasi D. 2012. Aerobic rice-mitigating water stress for the future climate change. Int J Agron Plant Prod, 3(7), :241-254.

Pathak H, Tewari AN, Sankhyan S, Dubey DS, Mina U, Singh VK, Jain N, Bhatia A. 2011. Direct-seeded rice: Potential, performance and problems-A review. Current Advances in Agricultural Sciences, 3(2): 77-88.

Pongprasert S. 1995. Insect and disease control in wet seeded rice in Thailand. IRRI Discussion Paper Series (Philippines).

Ponnamperuma FN. 1972. Elsevier, The chemistry of submerged soils. In Advances in agronomy (24): 29-96.

Purugganan MD. 2010. The evolution of rice: Molecular vignettes on its origins and spread. Archaeological and Anthropological Sciences, 2(2): 61-68.

Qureshi AS, Masih I, Turral H. 2004. Comparing land and water productivities of transplanted and direct dry seeded rice for Pakistani Punjab. Paddy and Water Environment.

Ragvendra T, Suresh BG, Mishra VK, Ashutosh K, Ashok K. 2011. Genetic variability and character association in direct seeded upland rice (Oryza sativa). Environment and Ecology, 29(4A):2132-2135.

Rani Sinniah, U., Wahyuni, S., Syahputra, B. S. A., and Gantait, S. 2012. A potential retardant for lodging resistance in direct seeded rice (Oryza sativa L.). Canadian Journal of Plant Science, 92(1):13-18.

Rao AN, Johnson DE, Sivaprasad B, Ladha JK, Mortimer AM. 2007. Weed management in direct-seeded rice. Advances in Agronomy, 93:153-255.

Rehman A, Farooq M, Ata Cheema Z, Nawaz A, Wahid A. 2014. Foliage applied boron improves the panicle fertility, yield and biofortification of fine grain aromatic rice. Journal of Soil Science and Plant Nutrition, 14(3):723-733.

Rickman JF. 2002. Manual for laser land leveling (5). RiceWheat Consortium for the Indo-Gangetic Plains New Delhi.

Roychowdhury M, Jia Y-L, Cartwright RD. 2012. Structure, function, and co-evolution of rice blast resistance genes. Acta Agronomica Sinica, 38(3): 381-393.

Satter MA, Bhuiyan SI. 1993. A study on the adoption of directseeded rice in some selected areas of Philippines. Farm Economy (Bangladesh).

Shah ML, Bhurer KP. 2005. Response of wet seeded rice varieties to sowing dates. Nepal Agriculture Research Journal, 6: 3948.

Shah T, Singh OP, Mukherji A. 2006. Some aspects of South Asia's groundwater irrigation economy: Analyses from a survey in India, Pakistan, Nepal Terai and Bangladesh. Hydrogeology Journal, 14(3): 286-309.

Shelley IJ, Takahashi-Nosaka M, Kano-Nakata M, Haque MS, Inukai Y. 2016. Rice cultivation in Bangladesh: Present scenario, problems, and prospects. Journal of International Cooperation for Agricultural Development, 14(4): 20-29.

Sheng-xiang T. 2002. Seedling broadcasting in China: An overview. 2(4), 177-179.

Singh G, Singh Y. 2008. Integrated weed management in directseeded rice. Direct Seeding of Rice and Weed Management in the Irrigated Rice-Wheat Cropping System of the IndoGangetic Plains: 161-176.

Singh SP, Orr A, Singh S, Singh G. 2008. The economics of direct-seeded rice in eastern India. Direct Seeding of Rice and Weed Management in the Irrigated RiceWheat Cropping System of the Indo-Gangetic Plains:229.

Subbaiah SV. 2008. Studies on weed and water management in direct-seeded rice. Direct Seeding of Rice and Weed Management in the Irrigated Rice-Wheat Cropping System of the Indo-Gangetic Plains: 180-181. 
Sunam RK, McCarthy JF. 2016. Reconsidering the links between poverty, international labour migration, and agrarian change: Critical insights from Nepal. The Journal of Peasant Studies, 43(1): 39-63.https://doi.org/10.1080/03066150.2015.1041520

Tabbal DF, Bouman BAM, Bhuiyan SI, Sibayan EB, Sattar MA. 2002. On-farm strategies for reducing water input in irrigated rice; case studies in the Philippines. Agricultural Water Management, 56(2), 93-112.

Tomar VS. 2002. The beushening system of rice crop stablishment in eastern India. International Workshop on

Direct Seeding in Asian Rice Systems'. (Eds S Pandey, M Mortimer, L Wade, TP Tuong, K Lopez, B Hardy) : 53- 74.

Tripathi RS, Raju R, Thimmappa K. 2014. Economics of direct seeded and transplanted methods of rice production in Haryana. Seeds (Kg Ha-1), 12(23.78): 92-57.

Tuong TP, Wopereis MCS, Marquez JA, Kropff MJ. 1994. Mechanisms and control of percolation losses in irrigated puddled rice fields. Soil Science Society of America Journal, 58(6): 1794-1803.

Tyagi R, Chander JKS. 2020. Comparative analysis between direct seeded rice and conventional transplanted rice method.

Van der Ploeg JD. 2009. The new peasantries: Struggles for autonomy and sustainability in an era of empire and globalization. Routledge.

Vandergeest P. 2012. Deagrarianization and reagrarianization: Multiple pathways of change on the Sathing Phra Peninsula. Revisiting Rural Places: Pathways to Poverty and Prosperity in Southeast Asia: 135-156. Vasudevan, P., Kavitha, S., Priyadarisini, V. B., Babujee, L., and

Gnanamanickam SS. 2002. Biological control of rice diseases. Biological Control of Crop Diseases. Gnanamanickam Ed. Marcel Dekker Inc, New York, 11-32.
Wada T. 2002. Influences of changing from transplanting to direct seeding on the status of some pest species. Direct Seeding: Research Strategies and Opportunities: 341-348.

Weerakoon WMW, Mutunayake MMP, Bandara C, Rao AN, Bhandari DC, Ladha JK. 2011a. Directseeded rice culture in Sri Lanka: Lessons from farmers. Field Crops Research, 121(1): 53-63.

Weerakoon WMW, Mutunayake MMP, Bandara C, Rao AN, Bhandari DC, Ladha JK. 2011b. Directseeded rice culture in Sri Lanka: Lessons from farmers. Field Crops Research, 121(1): 53-63.

Yadav GS, Babu S, Das A, Mohapatra KP, Singh R, Avasthe R. K, Roy S. 2020. No-till and mulching enhance energy use efficiency and reduce carbon footprint of a direct-seeded upland rice production system. Journal of Cleaner Production, 271, 122700.

Yadav S, Singh UM, Naik SM, Venkateshwarlu C, Ramayya P. J, Raman KA, Sandhu N, Kumar A. 2017. Molecular mapping of QTLs associated with lodging resistance in dry direct-seeded rice (Oryza sativa L.). Frontiers in Plant Science, 8, 1431.

Yaduraju NT, Mishra JS. 2008. Sedges in rice culture and their management. Direct Seeding of Rice and Weed Management in the Irrigated Rice-Wheat Cropping System of the IndoGangetic Plains: 191-203.

Yamauchi T, Shimamura S, Nakazono M, Mochizuki T. 2013. Aerenchyma formation in crop species: A review. Field Crops Research, 152: 8-16.

Zhao DL, Atlin GN, Bastiaans L, Spiertz JHJ. 2006. Cultivar Weed-Competitiveness in Aerobic Rice: Heritability, Correlated Traits, and the Potential for Indirect Selection in Weed-Free Environments. Crop Science, 46(1): 372-380. https://doi.org/10.2135/cropsci2005.0192

Zhao Z. 2010. New data and new issues for the study of origin of rice agriculture in China. Archaeological and Anthropological Sciences, 2(2): 99-105. 